\title{
Transforming water resources management in South Africa. 'Catchment management agencies' and the ideal of democratic development
}

\author{
Magalie Bourblanc ${ }^{1,2 *}$ \\ ${ }^{1}$ CIRAD UMR G-EAU, Montpellier, France \\ ${ }^{2}$ Centre for Environmental Economics and Policy in Africa, University of Pretoria, \\ Pretoria, South Africa
}

\begin{abstract}
This article addresses the dilemma of the democratic development of water resources management in the context of Post-Apartheid South Africa and unequal access to water. Using a political sociology of public policy approach as a conceptual framework, this article focuses on the actual functioning of the catchment management agencies (CMAs). On the basis of case studies' analysis, it is argued that CMAs are essentially political arenas although the semi-structured interviews conducted reveal that this political dimension is mainly denied by most of CMAs members and staff as well as by policy makers. Finally, the risks of professionalising interest representation within CMAs are evoked. Copyright (c) 2012 John Wiley \& Sons, Ltd.
\end{abstract}

Keywords: water; South Africa; catchment management agencies; democratic development; social transformation; policy implementation; rules of the game; representatives' selection

\section{Introduction}

There is a trend across the world towards the standardisation of water policies around four main principles: river basin management, stakeholders' participation, reparation and sustainable development paradigm applied to aquatic ecosystems (Brun and Lasserre, 2006). Noticeably, the South African water reform policy has not been immune to the influence of so-called international best practices of water resource management as was shown in literature (Biggs et al., 2008) and acknowledged by public authorities themselves (DWAF, 2003). The adoption of a new National Water Act (NWA) in 1998 has been

*Correspondence to: Magalie Bourblanc, Centre for Environmental Economics and Policy in Africa, University of Pretoria, Private Bag X20 Hatfield, Pretoria 0028, South Africa.

E-mail: magalie.bourblanc@cirad.fr 
largely inspired by these international standards such as the ones which have gained acceptance after the 1992 International Conference on Water and the Environment in Dublin or the principles emerging during the United Nations Earth Summit in Rio de Janeiro (1992). These principles are often encapsulated under the paradigm of 'integrated water resource management' (IWRM) and include stakeholders' participation, decentralisation and river basin organisations, just to mention a few. This international influence is not surprising because countries which go through a major economic and political regime shift are particularly prone to the importation of international norms into their national system (Delpeuch, 2009).

The creation of decentralised water resources management institutions such as the catchment management agencies (CMAs) is a concrete translation of this IWRM principle. However, tracing back the genealogy of the principles that inspired the South African Legislator and fed the White Paper on a National Water Policy for South Africa in April 1997, then the NWA itself, is beyond the scope of this article. Instead, this contribution addresses the criticisms that the IWRM principles are too much of a Western concept (de Lange, 2004) promoted worldwide by the World Bank and other closely linked organisations such as the Global Water Partnership and the World Water Council in a 'one-size-fits-all' toolbox approach (Laube, 2010). In response, some authors have emphasised how context specific the management of water resources is and have called for a re-politicising of the analysis of the issue (Scheumann et al., 2008; Berry and Mollard, 2010; Boelens et al., 2010). In that respect for instance, the systematic reference to the ecological territory of the river basin is being disputed now for its lack of relevance from a political viewpoint (Warner et al., 2008).

Likewise, Mollinga (2008) visualised the management of water resources as a 'politically contested water control' activity. For Mollinga, 'water control' has three dimensions: a technical/physical one, an organisational/managerial one and a socioeconomic and regulatory one. The author shows that the managerial dimension is only one aspect of the phenomenon under consideration. Similarly, critical management studies have also criticised the now widespread idea that 'only management can do organisation' (Parker, 2002, p. 11), ignoring alternative forms of organising. Moreover, Parker distinguishes between the concept of 'management', which is linked to the 'processes of ordering and controlling people and things' (p. 7), and the concept of 'managerialism', which corresponds to 'the generalised ideology of management' (p. 10). In addition, managerialism represents a particular approach of management activities in which the roots are associated with the practices of business organisations (Roberts et al., 2005). In the following sections, the use of the adjective 'managerial' will refer to management issues conceived as the specific tasks performed by managers whereas the use of the word 'managerialist' will refer to managerialism and market based conception of organisation.

This article situates itself in the legacy of Mollinga's research programme revolving around a 'political sociology of water resources management' (Mollinga, 2008). It focuses on two of the four domains of political contestation listed under his water research agenda, namely, the everyday politics of water resources management and the politics of state policy. Because only little has been written on the actual running of the CMAs, the article raises the question of their practical functioning. In this regard, it follows the tradition of public policy analysis which, putting into perspective the adopted objectives and their concrete achievement, emphasises the implementation phase in the policy-making process (Pressman and Wildavsky, 1973).

Indeed very often, most of the political analyses of water resources management revolve around the selection criteria for an effective participation (Cooke and Kothari, 2001) and a 
'substantive stakeholder representation' in general (Wester et al., 2003) or in particular as in the South African context (Wilson and Perret, 2010). However, theses analyses focus on an actor's perspective only. This contribution goes beyond actors' initial characteristics and pays attention to the rules of the game, either formal or informal within CMAs. According to Ostrom et al. (1994, p. 38), 'rules [...] are prescriptions that define what actions (or outcomes) are required, prohibited, or permitted [. . .]'. In other words, the rules of the game refer to the context in which actors operate. Far from being a neutral issue, these rules sway the way representatives can participate within a decision-making process and get to implement a particular agenda, or in the present case, what and how they have to perform within the CMAs.

In the following sections, the article demonstrates that, considering their mandate, CMAs are fundamentally political arenas. Practically, however, most of their members as well as policy makers perceive them from a managerialist viewpoint only. Finally, potential discrepancies between CMAs' daily routine and their legislative political mandate are speculated, and some risks linked to the confusion between managerial means and ends are exposed. The article relies on in-depth case studies about two existing CMAs in South Africa-Breede-over-Berg CMA (BOCMA; Western Cape province) and Inkomati CMA (Mpumalanga province) — as well as on field work centred around three other gazetted CMAs in Tugela and Usutu to Mhlatuze (KwaZuluNatal) and in Crocodile West and Marico (northwest province). One hundred interviews were conducted during these case studies between June 2010 and March 2011, with various stakeholders' representatives having participated in the water fora, CMA staff and governing board (GB) members, Department of Water Affairs (DWA) officials and political elites at local and provincial levels. ${ }^{1}$ Those were semi-structured interviews. Questions asked during these interviews revolved around the practical modes of participation for each GB members, the topics discussed during GB meetings, the drafting process of strategic CMA's documents and a description of the sharing of responsibilities between the GB and the CMA's staff.

\section{The political dimension around water issues in South Africa}

First, it is important to note that there are critical stakes attached to water issues in South Africa. Indeed, given the country's semi-arid climate, water issues are considered with a particular interest in South Africa. Notwithstanding its biophysical conditions, the historical context of the country has also illustrated how much water has always played a crucial role in development through commercial farming, mining activities, dams' electricity production, and so on (Turton and Henwood, 2002; Mollinga, 2008). Indeed, some authors (Blanchon, 2009; Swatuk, 2010) speak about South Africa as a country vested with a hydraulic mission that has been crucial in the societal narratives and instrumental in the construction of the state. Against this background for instance, the South African DWA has represented for a long time a typical 'hydrocracy' (Molle et al., 2009), that is, a very powerful administration in state apparatus: a hydraulic bureaucracy resting on a

\footnotetext{
${ }^{1}$ Although the NWA announced the creation of 19 CMAs, only eight of them had been gazetted, and only two are considered functional.
} 
highly qualified corps of engineers building canals, dams and other gigantic infrastructures on rivers.

Till now, water holds a crucial role in the South African context and the 1998 NWA reforming water policies recognises that there is a 'need to promote social and economic development through the use of water' (DWA, 1998). On ascension to power in 1994, the new ruling democratic regime made this sector a priority policy to demonstrate its will to redress inequalities inherited from the past (Blanchon, 2009). Indeed, access to water still displays the most striking inequalities of all the policies: white large-scale farmers consumed as much as $95 \%$ of water for irrigation, whereas smallholders, mainly black farmers, share the remaining 5\% (Schreiner and Van Koppen, 2002; Cullis and Van Koppen, 2007). Considering the stakes involved, the water sector appears as a very symbolic issue in the struggle for 'social transformation', ${ }^{2}$ that is, the struggle to redeem past inequalities and rebuild the nation around the achievement of an equitable water policy reform.

Against this background, in 1996, South Africa became the first country in the world with a constitution providing a right to water (RSA, 1996). ${ }^{3}$ Moreover, it is widely acknowledged that the new Water Act of South Africa constitutes one of the most progressive water laws in the world (Biggs et al., 2008). The NWA recognises explicitly that because 'the discriminatory laws and practices of the past have prevented equal access to water, and use of water resources', one of the objectives of the NWA is 'to redress the results of past racial and gender discrimination in the use of water resources' (DWA, 1998, schedule 4, part 4, provision 24). Since 1998, the National Department of Water Affairs is supposed to progressively delegate a major part of its functions in terms of water resource management to 19 CMAs whose GB is composed of different water users' representatives. Once a CMA is fully functional, it will be responsible for most water resources management functions within a specific river basin, including the authorisation of water use. The DWA will however retain certain strategic functions such as the determination of international water allocations, the allocation to national strategic industries and the determination of inter-basin transfers (Karar et al., 2011). Therefore, although the national level will keep an institutional oversight function at all moment, CMAs are far from being endowed with anecdotal responsibilities because the initial functions of CMAs include, inter alia, the responsibility to regulate and co-ordinate related activities of water users and of water management institutions within its area, including the authorisation of water use and the responsibility to promote community participation in the protection, use, development, conservation, management and control of water resources; the responsibility to develop a Catchment Management Strategy (CMS), which although it has to be consistent with the National Water Resource Strategy, nonetheless prevails over the decisions that will be taken for water resources management and integrated planning within the CMA's area of jurisdiction.

There is little surprise then that there are political manoeuvres around CMAs' GB composition. The field work conducted reveals that politics are at play concerning the generic composition of the GB, with the determination of which interests should be represented for the dozen seats granted to stakeholders' representatives. Politics are also at play concerning the designation of individuals who are to represent the interest groups. It seems that very often the designation of such personalities involves political games. These political games have various dimensions. First, they can be related to racially based politics

\footnotetext{
2idem.

${ }^{3}$ 'Everyone has the right to have access to [...] sufficient water'.
} 
with the objective of ensuring that most seats within the GB will be granted to former disadvantaged groups, or on the contrary to sections of the population who benefited previously. Indeed, this political influence goes both ways: in BOCMA for instance, commercial farming managed to secure four seats to themselves through different portfolios, raising the issue of the balance among different interests within the CMA. Second, there is another political dimension linked to party politics. Here the intent of political parties is to ensure that specific policy agenda will be supported within the GB. Finally, there is a dimension attached to the political clientele. By nominating personalities that are close to one's political party network, the idea is not to defend particular policies' priorities but to reward the loyalty or allegiance of individuals to the political network.

\section{The CMAs as political arenas}

Focussing on policy implementation, one realises that CMAs have to operate in a difficult landscape. Numerous academic works have identified a backlog in the implementation of the redistributive agenda and that inequalities were still apparent almost 15 years after the end of Apartheid (Merrey et al., 2009). In reaction to this, the Water Allocation Reform Strategy of 2008 sets more concrete targets than the ones contained in the NWA. By 2014 , it seeks a proportion of $30 \%$ of allocable water to benefit Black people; by 2024 , the target is $60 \%$, of which half should be under control of black women (http://www. dwa.gov.za/WAR/documents/WARStrategySep08.pdf).

Against this background, CMAs are given very little direction from the regulator to determine how to fill this implementation gap and especially how to strike a balance between competing objectives. Indeed, the purpose of the South African NWA is to ensure that an 'efficient, sustainable and beneficial use of water in the public interest' (DWA, 1998, section 2) will be promoted. Both social justice and economic productivity of water are endorsed by the Act. According to this last principle, people demonstrating the most productive use of water should retain their user rights, meaning existing lawful water users who are making efficient use of water and contributing to socioeconomic growth would not be necessarily curtailed. However, how, in a water-scarce country, this goal will be accommodated with the objective of enabling a more equitable access to water resources or with the objective of alleviating poverty in rural areas where people engage in subsistence agriculture remains unanswered. Similarly, Perry et al. (1997) has underlined the imprecise character of some of the internationally acclaimed IWRM principles. For instance, the recognition of water as an economic good does not specify whether one deals with a private or public social economic good. Not only can some of these principles be rather vague, but they can also be occasionally antagonistic. In that respect, Molle evokes the fact that the Global Water Partnership, which promotes the three desired 'E's of IWRM (efficiency, equity and environmental sustainability), wrongly asserts that these three goals can be achieved altogether, providing people make a good use of rational thinking, expert knowledge and good science. On the contrary, the author shows that trade-offs among these will be necessary yet quite hard to reach (Molle, 2008).

CMAs are therefore facing important challenges. Indeed, more than anywhere else, water resource management in South Africa has always been intertwined with political considerations. Solving the uncertainties and approximations of the NWA implies having a political debate within the CMA, which cannot rely on a methodological toolkit that disregards the specific political and historical context in which they have to be applied. 
On the ground, how for instance to cater for both the needs of a growing population in former 'homelands' and the water rights previously granted to economic activities? As part of the reserve which is a right constitutionally guaranteed, human daily needs will always be prioritised together with the ecological reserve, which promotes a sustainable environment but has not been implemented yet. Economic interests can only be accommodated once basic human and ecological needs have been met, which is likely to cause some difficulties in a water-stressed area such as the Inkomati. How then in a context of increasing scarcity should the interests of profitable commercial farming be reconciled with the needs for water of emerging black farmers? Should the needs of former disadvantaged communities prevail over the needs of the commercial agriculture sector, which has already proved that it is productive, efficient and contributes to the socioeconomic growth? Because some NWA objectives are not as straightforward as expected, governing a CMA cannot be considered as a purely managerial task.

\section{Ruling a CMA with a managerialist stance}

However, the evidence concerning the political nature of CMAs tasks does not seem to match what a large number of the people interviewed during the case studies believe to be the core identity of the CMAs. Indeed, in contrast to the political mandate of CMAs, several of the interviewees, either members of the CMA's GB or of its staff, have often used the term company ${ }^{4}$ to designate their CMA. Likewise, the use of the term customers $^{5}$ to talk about water stakeholders reveals the particular mindset through which the work of the CMA is perceived. This vocabulary is actually in line with the 'enterprise approach' that former senior managers of the DWA have been advocating (Karar et al., 2011). It reflects the managerialist imperative that seems to have taken over the ruling of CMAs. Here, the managerialist imperative refers to the work of Roberts et al. (2005), who, speaking about NGOs' administration, regret that managerial oversight 'can take on a life of its own' (p. 1850). Here as well, managerial concern seems to have expanded beyond the perimeter of the CMA's staff activity and to be taken as the new goal of the CMA organisation rather than being a means to achieve a political goal.

This managerial imperative can be observed in the division of tasks between the CMA's GB and its staff in Inkomati and Breede-over-Berg basins. The division of tasks between CMA decision-making body - the GB and CMA officials, whose role is to execute the decisions adopted by the GB (Karar et al., 2011), does not seem to be respected. The CMA's staff responsibility is to assist the GB technically in the performance of its tasks, not to take over it. In particular, the drafting of the CMS cannot be undertaken for its most part by the staff, leaving the GB only to register options that have been put on the agenda by the CMA officials, as was the case in Inkomati. ${ }^{6}$ This is a very critical aspect as, conversely to what was exposed by one GB member in the Inkomati case, the CMS is

\footnotetext{
${ }^{4}$ Interview commercial agriculture representative, Inkomati CMA, June 2010; Interview representative of industry, power generation and mining, Inkomati CMA governing board, February 2011; Interview secretary ICMA Governing Board, February 2011; Interview commercial agriculture representative, Crocodile West and Marico CMA, March 2011; Interview representative of Industry and Business, BOCMA governing board, November 2010. ${ }^{5}$ Interview commercial agriculture representative, Inkomati CMA, June 2010; Interview representative of industry, power generation and mining, Inkomati CMA governing board, February 2011; Interview commercial agriculture representative, Crocodile West and Marico CMA, March 2011.

${ }^{6}$ Interview acting CEO of Inkomati CMA; Interview secretary ICMA Governing Board, February 2011.
} 
not merely a 'practical document', positioning itself very 'far away from politics', meaning a document within which no political consideration or political stance should take place whatsoever. ${ }^{7}$ Indeed, the NWA mentions that a CMS will include, for instance, a water allocation plan and that it must set principles for allocating water to existing and prospective users, taking into account all matters relevant to the protection, use, development, conservation, management and control of water resources (DWA, 1998, chapter 2, part 2).

Several reasons could be raised to justify why it is not satisfactory to let the CMA officials take priority over the GB discussion on the matter, but the most convincing one is certainly the potential structural bias of the staff towards commercial farming already mentioned in the literature (Brown and Woodhouse, 2004), that is, the fact that the job security of CMAs officials depends on financial resources that will be everywhere mainly provided, at least in the early stages, by the commercial-mainly White-farmers. ${ }^{8}$ Consequently, it is not difficult to foresee a potential conflict of interest for officials. That is why among other reasons they are supposed to refrain from engaging with any kind of political decisions, and especially the ones that are enclosed in a CMS, which according to the law have to remain under the exclusive responsibility of the GB.

Finally, it seems that to some extent the 'corporate' vocabulary used has to do with the concern with the financial sustainability of the CMA organisation. However, if securing its economic sustainability is an important pre-requisite of the capacity of a CMA to fulfil its mission, it cannot pass as its goal. According to the law, if CMAs are to act in accordance with a 3-year business plan, matters to be considered in setting financial targets include corrective action to redeem inherited inequities (DWA, 1998, schedule 4, part 4, provision 24).

\section{Risks attached to confusing managerial means and ends}

Considering the CMAs as an enterprise can be seen as a typical example of confusion between what was supposed to be a means, among others, and what has now become almost the ultimate end goal. One potential risk of considering the CMAs as an enterprise can be addressed, in particular. Early research already evoked the risk of 'capture' of new participatory institutions by vested interests pointing at the influence of commercial farming sector on future CMAs (Woodhouse, 1995). Likewise, the request from some Inkomati GB members to set water charge fees to which they are subject in a bottom-up approach, based on the willingness to pay of water stakeholders, ${ }^{9}$ is problematic. Indeed, one CMA GB member interviewed claimed that under the new approach, if water users were ready to pay an increase in the tariff, it would have to be proportionate to what the CMA can deliver to them, implying that water users are CMA's mere clients. Yet, in the spirit of the Act, the idea of decentralising water governance at the river basin level and asking stakeholders to participate in decision making was conceived to adapt decisions better to the local context and not to give an opportunity to these stakeholders to redefine national water policy agenda to suit their particular needs. It was intended that stakeholders should respond to national objectives, not only seeking their own individual interests, which in our particular case would be to maintain water tariff as low as possible for the different interest groups.

\footnotetext{
${ }^{7}$ Interview commercial agriculture representative, Inkomati CMA, June 2010.

${ }^{8}$ So far, the Inkomati CMA has two funding sources: first, a parliamentary allocation that comes from government coffers, and second, an external funding that comes from the donor community.

${ }^{9}$ Interview representative of industry, power generation and mining, Inkomati CMA governing board, February 2011.
} 
Another direct consequence of considering CMAs as mere 'companies', in which the main goal is to draft and implement a business plan, can be found in the insistence on the professionalisation of GB members. Indeed, in the case of Inkomati CMA, the appointment of a new GB is under way, ${ }^{10}$ and one of the criteria of the advisory committee to select new representatives has been to check that candidates level up to the technical knowledge required to actively participate in the discussion. ${ }^{11}$ This is equivalent to selecting GB members based on their sole competence, that is, mere experts of water issues who will not have to benefit from a political legitimacy within the group they will represent to be selected. Surely, some good reasons can be found to support a professionalisation requirement. Indeed, considering the complexity of water issues, the GB's commitment is largely depending on the capacity of its members to participate in the discussions from a technical perspective. In that respect, it has already been mentioned several times that some stakeholders in particular benefit from substantial discursive advantages in the South African water reform debate : 'Well resourced stakeholders, such as forestry, mining, sugar and metropolitan municipalities have demonstrated their superior leverage through effective scientific, economic and legal advice, leaving marginalised groups such as emerging farmers behind. Efforts should be directed towards balancing the scales of knowledge equity' (Asnar and Hansen, 2009, p. 8). The actual functioning of Inkomati CMA is confirming this feature with commercial farming, electricity production and tourism interests' representatives, to mention but a few, dominating the exchanges, whereas the Historically Disadvantaged Individuals' representative, the Civics representative and the informal settlements' representative in particular have a tendency to remain rather passive. The same comment about the passivity of informal settlements' representative in BOCMA could be made. This alleged passivity may be linked to a low level of confidence because of the lower levels of knowledge on water resources and, to a great extent, the differences in educational levels among board members that could also be observed during the interviews conducted.

However, this passivity is especially striking when compared with empirical literature on the broad consultation phase before the Inkomati CMA official establishment. Indeed Anderson (2005, p. 5) evoked the fact that 'During the participatory process there was a lack of clarity on important data such as the water balance (reconciliation of water requirements and water availability) for the three sub-catchments. This created tension between stakeholders as each sector blamed the other for water scarcity and over-allocations'. This statement contrasts very much with the current situation that was observed during field work in the Inkomati river basin in 2010-2011 in which no such tension could be noticed. This should be an encouraging statement if it could be attributed to the pacification of relations among various stakeholders and to a social learning process on how to interact in a constructive way over difficult issues. However, a better explanation seems to be residing in the fact that stakeholders' representatives are not always engaging with the major challenges facing water resources management in the river basin and have a tendency to overlook the crucial stakes that should be debated within the CMA. Indeed, the lack of tension is best explained by the fact that contentious subjects are avoided within the GB meetings even during strategic discussions like the one over the CMS drafting. Such a

\footnotetext{
${ }^{10}$ According to the law, the renewal of the governing board is a two-step process: an advisory committee, composed of water experts (who can also be former GB members) is designated for every single CMA. For each interest group representative, it proposes three names and sends this recommendation to the DWA Minister who has the final say in the appointment of GB members.

${ }^{11}$ This is also a viewpoint favoured by former high-ranked managers of the DWA (see Karar et al., 2011).
} 
gap between stakeholders' preoccupations and their representatives raises the question of representativeness of the GB members and their legitimacy to voice the concerns of the population that they are supposed to be speaking on behalf of and being accountable to. It is especially important to pay attention to this kind of risk in the CMA representatives' selection process because disadvantaged communities have had a tendency over the past to be suspicious towards the CMA organisation: during participatory water forums for instance, according to one of the interviewees, many disadvantaged communities got the impression that the CMA establishment process was an initiative delaying their longawaited opportunity to get an access to water resources. ${ }^{12}$

Linked to the issue of professionalisation of the GB, one decision taken by Inkomati CMA GB could be seen as counterproductive: the decision to allocate a stipend almost amounting to a salary to its members. Indeed, the prospect of receiving a salary out of one's participation into the GB gives negative incentives. The Crocodile West and Marico water forums process illustrates that point particularly well. Indeed, according to one of the interviewees, 'once people realised they wouldn't get paid, they disappeared; the consultation process had to start all over again, amounting to big delays in the establishment process of the CMA and to the exasperation of other members'. ${ }^{13}$ The prospects of getting paid for participating in the process may have repercussions on the commitment and accountability of GB members: it could attract the wrong candidates for stakeholders' representation. Making things clearer about money prospects from the very start might help avoid these misunderstandings and delays in the selection of truly motivated participants in the consultation process. Even for population categories struggling with the necessity to make a decent living, participating in CMA GB cannot be perceived as a way to derive revenue. On the contrary, it has to be considered as volunteering work. According to this principle, BOCMA has only allowed a small stipend covering extra costs of participation to four meetings per year (transport expenditures, food expenditures, etc.). This might be an efficient way of preventing any conflict of interests between members who could be tempted to censor their (constructive) critical thought about the CMA's agenda or to be overtly laudatory about CMA's program of actions because of their fear of undermining the organisation that ensures their very subsistence. By being too demanding about the expertise level of potential representatives, one faces the risk to see the professionalisation requirement provoke a detrimental impact on the end goal of CMAs, although this negative dimension has not been specifically mentioned by the interviewees. This detrimental effect has here to do with the prospect of favouring competence over representativeness, which ultimately alters the agenda of CMAs.

\section{Conclusion}

During the past few years, a call for re-politicising analyses of water resources management has been endorsed by a growing number of contributions, including contributions that account for the South African experience. However, most of these contributions have focussed on stakeholders' selection for effective participation, that is, on an actor's approach. Only little has been said on how these actors perform once being selected.

\footnotetext{
${ }^{12}$ Interview Inkomati CMA Governing Board chairperson, June 2010.

${ }^{13}$ Interview Rustenburg Transitional Local Council representative, Crocodile West and Marico CMA, March 2011.
} 
However, more than anything else, the rules in use determine the actors' ability to play a significant role in the decision-making process. Following a political sociology of water resources management's analytical framework (Mollinga, 2008), the article remedies this situation by focusing on the rules of the game: the article interrogates the actual functioning of CMAs, observing the potential gap between adopted legislative objectives and their practical implementation.

The article has demonstrated that considering their legislative mandate, the CMAs have to deal with political issues. In particular, they have to tackle competing objectives that require an adequate and open deliberation to be sorted out, as well as an arbitration arena in which potential disputes can be settled. In practice, however, the present case studies reveal that so far this political dimension has been denied by prominent GB members and policy makers. The article moves on to argue that although dealing with practical aspects of water management, this does not entail for CMAs that water-related managing activities have to be endorsed with a water-related managerialist approach necessarily. What this means is that if economic and financial health is a pre-requisite of CMAs' sustainability, the managerialist imperative promoted by several CMA's members and policy makers should not be confused with CMAs' core goal. The article shows how this managerialist approach can sometimes be at odds with the struggle for social transformation in South African water issues.

Similarly, the article also exposes how CMAs displaced the stated end goals of the organisation by developing politics of their own that ultimately generated advantages to individual actors rather than to local communities. Therefore, if the article's objective has been to demonstrate that GB members are part of a political arena and that they are in charge of a political mandate, here 'political' should not be confused with 'politics' (or political factions), especially in the context of local government mismanagement in South Africa (COGTA, 2009) and even corruption practices allegedly linked to party politics (Atkinson, 2007). Instead, what 'political' here has been referring to goes down to the most generic sense of the word, that is, 'political' in the sense of a 'polity', which arbitrates among different-sometimes conflicting-uses.

In any case, the call embraced in this article to re-politicise water resources management has prompted to take a closer look at means and ends and to discuss more explicitly their adequacy in water management practices as in the case of the professionalisation requirement. It was argued that there is definitely a domain where managerial principles could be applied to issues about water resources management in South Africa, but they should be circumscribed to the hired staff component of a CMA, and not extended to its GB. This implies that a clearer division of work is abided by these two bodies of a CMA. Subsequently, the article also underlined how the requirement for the GB to be versed in managerial sound practices and business plan drafting could have negative consequences on the primary political objective. The selection of the GB members in particular has also been depicted as a sensitive process to conduct, one that deserves very keen attention to avoid some of the traps mentioned earlier: either to avoid selecting passive/non-dedicated members to its political agenda or to avoid favouring competence over representativeness as it seems to be the case for the list selected by the Inkomati advisory committee for the renewal of the CMA GB. In that respect, if continuous efforts are dedicated to the training of GB members and staff, CMAs might circumvent having any intimidated member not daring to raise his or her voice during meetings, and ultimately CMAs might ensure a real empowerment of their members. 


\section{Acknowledgments}

The research project underlying this article was funded by the French Embassy of South Africa and the South African Department of Science and Technology as part of the Joint South African-French network for research in science and technology-SAFeWater Arise project: New Water Governance over Water Resources for Sustainable Rural Development: Research on Social, Economic and Institutional Aspects.

\section{References}

Anderson AJ. 2005. Engaging disadvantaged communities: lessons from the Inkomati CMA establishment process. Paper presented at the African Water Laws: plural legislative frameworks for rural water management in Africa, Johannesburg. 26-28 january 2005.

Asnar M, Hansen M. 2009. Water legislation-which values, Which ways? Paper presented at the Human Dimensions of Global Environmental Change, Amsterdam. 2-4 December 2009.

Atkinson D. 2007. Taking to the streets: has developmental local government failed in South Africa? In State of the Nation: South Africa 2007, Buhlungu S, Daniel J, Lutchman J, Southall R (eds). HSRC Press: Cape Town; 53-77.

Berry KA, Mollard E (eds). 2010. Social participation in water governance and managament: criticl and global perspectives. Earthscan: London.

Biggs HC, Breen CM, Palmer CG. 2008. Engaging a window of Opportunity. Synchronicity between a Regional River Conservation Initiative and Broader Water Law Reform in South Africa. International Journal of Water Resources Development 24(3): 329-343.

Blanchon D. 2009. L'espace hydraulique sud-africain. Karthala: Paris.

Boelens R, Getches D, Guevara Gil A (eds). 2010. Out of the mainstream. Water rights, Politics and Identity. Earthscan: London.

Brown J, Woodhouse P. 2004. Pioneering redistributive regulatory reform. Working paper series: 89. Centre on regulation and competition, University of Manchester: Manchester, November 2004.

Brun A, Lasserre F. 2006. Les politiques de l'eau. Grands principes et réalités locales. Presses de l'université de Québec: Québec.

COGTA. 2009. State of local government in South Africa. Overview report: National state of local government assessments. Department of cooperative government and traditional affairs: Pretoria.

Cooke B, Kothari U (eds). 2001. Participation: the new tyranny? Zed Books: London.

Cullis J, Van Koppen B. 2007. Applying the Gini Coefficient to Measure Inequality of Water Use in the Olifants River Water Management Area, South Africa. IWMI research report: 113. International Water Management Institute: Colombo.

Delpeuch T. 2009. Comprendre la circulation internationale des solutions d'action publique: panorama des policy transfer studies. Critique internationale 43(2): 153-165. doi: 10.3917/ crii.043.0153

DWA. 1998. National Water Act—no. 36 of 1998. DWA: Pretoria.

DWAF. 2003. Resources Directed Measures-Module 1 Introductory Module. DWAF: Pretoria.

Karar E, Mazibuko G, Gyedu-Ababio T, Weston D. 2011. Catchment Management Agencies: a case study of institutional reform in South Africa. In Transforming water management in South Africa. Designing and implementing a new policy framework, Schreiner B, Hassan R (eds). Springer: London; 145-164.

de Lange M. 2004. Water policy and law review process in South Africa with a focus on the agricultural sector. In The politics of irrigation reform: contested policy formulation and implementation 
in Asia, Africa and Latin America, Mollinga PP, Bolding A (eds). Ashgate: Aldershot (Engl.); $11-56$

Laube W. 2010. Changing the course of history? Contextualising the adoption and implementation of water policies in Ghana and South Africa. In When policy meets reality. Political dynamics and the practice of integration in water resources management reform, Mollinga P. P., Bhat A, Saravan VS (eds). LIT Verlag: Berlin.

Merrey DJ, Lévite H, Van Koppen B. 2009. Are good intentions leading to good outcomes? Continuities in social, economic and hydro-political trajectories in the Olifants river basin, South Africa. In River basin trajectories: societies, environment and development, Molle F, Wester P (eds). CAB International: Wallingford; 47-74.

Molle F. 2008. Nirvana concepts, narratives and policy models: insight from the water sector. Water Alternatives 1(1): 131-156.

Molle F, Mollinga PP, Wester P. 2009. Hydraulic bureaucracies and the hydraulic mission: flows of water, flows of power. Water Alternatives 2(3): 328-349.

Mollinga PP. 2008. Water, politics and development. Water Alternatives 1(1): 7-23.

Ostrom E, Gardner R, Walker J. 1994. Rules, games, \& common-pool resources. The University of Michigan Press: Ann Arbor.

Parker M. 2002. Against management: Organization in the age of managerialism. Blackwell Publishers Inc.: Malden (MA).

Perry C, Rock M, Seckler D. 1997. Water as an economic good: a solution or a problem? IWMI research report: 14. International Water Management Institute: Colombo.

Pressman JL, Wildavsky A. 1973. Implementation: How great expectations in Washington are dashed in Oakland. University of California Press: Berkeley.

Roberts SM, Jones JPI, Fröhling O. 2005. NGOs and the Globalization of Managerialism: a research framework. World Development 33(11): 1845-1864.

RSA. 1996. Constitution of the Republic of South Africa-Act $n^{\circ} 108$ of 1996. RSA: Pretoria.

Scheumann W, Neubert S, Kipping M (eds). 2008. Water politics and development cooperation. Local power plays and global governance. Springer: Berlin.

Schreiner B, Van Koppen B. 2002. Catchment Management Agencies for Poverty Eradication in South Africa. Physics and Chemistry of the Earth 27(11): 969-976. doi: http://dx.doi.org/ 10.1016/S1474-7065(02)00100-6

Swatuk LA. 2010. The State and Water Resources Development through the Lens of History. Water Alternatives 3(3): 521-536.

Turton AR, Henwood R. 2002. Hydropolitics in the developing world: a Southern African perspective. African Water Issues Research Unit, University of Pretoria: Pretoria.

Warner J, Wester P, Bolding A. 2008. Going with the flow: river basins as the natural units for water management? Water Policy 10(S2): 121-138. doi: 10.2166/wp.2008.210

Wester P, Merrey DJ, De Lange M. 2003. Boundaries of consent: stakeholder representation and river basin management in Mexico and South Africa. World Development 31(5): 797-812. doi: 10.1016/S0305-750X(03)00017-2

Wilson Z, Perret SR. 2010. Participation in water resource and services governance in South Africa: caught in the Acts. In Social participation in water governance and managament: critical and global perspectives, Berry KA, Mollard E (eds). Earthscan: London; 183-200.

Woodhouse P. 1995. Water Rights and Restructuring in South Africa: a case study from Eastern Transvaal. Water Resources Development 11(4): 527-544. doi: 10.1080/07900629550042182 